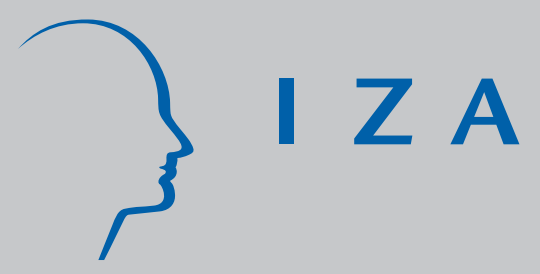

IZA DP No. 1736

The Occupational Attainment of American J ewry: 1990 to 2000

Barry R. Chiswick

September 2005 


\title{
The Occupational Attainment of American Jewry: 1990 to 2000
}

\author{
Barry R. Chiswick \\ University of Illinois at Chicago \\ and IZA Bonn
}

\section{Discussion Paper No. 1736 \\ September 2005}

\author{
IZA \\ P.O. Box 7240 \\ 53072 Bonn \\ Germany \\ Phone: +49-228-3894-0 \\ Fax: +49-228-3894-180 \\ Email: iza@iza.org
}

\begin{abstract}
Any opinions expressed here are those of the author(s) and not those of the institute. Research disseminated by IZA may include views on policy, but the institute itself takes no institutional policy positions.
\end{abstract}

The Institute for the Study of Labor (IZA) in Bonn is a local and virtual international research center and a place of communication between science, politics and business. IZA is an independent nonprofit company supported by Deutsche Post World Net. The center is associated with the University of Bonn and offers a stimulating research environment through its research networks, research support, and visitors and doctoral programs. IZA engages in (i) original and internationally competitive research in all fields of labor economics, (ii) development of policy concepts, and (iii) dissemination of research results and concepts to the interested public.

IZA Discussion Papers often represent preliminary work and are circulated to encourage discussion. Citation of such a paper should account for its provisional character. A revised version may be available directly from the author. 
IZA Discussion Paper No. 1736

September 2005

\section{ABSTRACT}

\section{The Occupational Attainment of American Jewry: 1990 to 2000}

This paper compares the occupational distributions in 1990 and 2000 of adult white men and women for American Jews and non-Jews, after adjusting for the changes in occupational classifications. The data are from the microdata files from the National Jewish Population Surveys (1990, 2000/01) and the 1990 and 2000 Censuses of Population. Among both men and women, American Jews had a greater proportion in the high level occupations (managerial and professional) in 1990, and the difference increased over the next decade. Among Jews and among non-Jews, there were only small gender differences in the proportions in the high level occupations. Thus, religion was more important than gender in explaining occupational patterns. American Jews of both genders experienced a continued decline in self-employment over the decade, and a continued shift among those in managerial and professional jobs away from self employment and toward being salaried workers.

JEL Classification: J15, J16, J22, Z1

Keywords: occupational attainment, Jews, religion, gender, National Jewish Population Survey

Corresponding author:

Barry R. Chiswick

Department of Economics (M/C 144)

University of Illinois at Chicago

601 South Morgan Street (2103 UH)

Chicago, IL 60607-7121

USA

Email: brchis@uic.edu 
July 22, 2005

“The Occupational Attainment of American Jewry: 1990 to 2000”

Barry R. Chiswick ${ }^{*}$

This paper is concerned with documenting the changes from 1990 to 2000 in the occupational attainment of adult Jewish men and women compared to their non-Jewish counterparts, based on Census and survey data. The analysis for men constitutes an extension of an earlier study that compared the occupational distributions of Jewish and other men from 1890 to 1990 (Chiswick 1999). This study for the first time includes a comparative occupational analysis for Jewish and other women. Moreover, it documents the effect in these occupational distributions of the changes in the occupational classifications used by the U.S. Bureau of Census that were the basis for the occupational classifications used in 1990 and 2000 Censes of Population and the National Jewish Population Surveys of 1990 and 2000/01.

\section{The Background}

The object of the earlier study (Chiswick 1999), as well as this one, was not to quantify the detailed occupational distributions (e.g., presser, tailor, etc.) but rather the broad occupational categories and degrees of self-employment that reflect both the relative skills the individual brings to the labor market, and the likely economic benefits from these skills. The analysis was limited to adult (age 25-64) males because until recent decades married women, whether Jewish

\footnotetext{
${ }^{*}$ Department of Economics and Jewish Studies Program, University of Illinois at Chicago. I appreciate the comments of Carmel U. Chiswick, the research assistance of Jidong Huang and assistance with the NJPS from Lawrence Kother-Berkowitz.
} 
or not, had relatively low rates of labor forces participation. ${ }^{1}$ The analysis was limited to whites to increase comparability since nearly all Jews in the United States are white (over 97 percent). Most of the twelve “data points” for the period covered, 1890 to 1990, are from U.S. government sources, primarily the decennial censuses, although other data points were from private sources, including the National Opinion Research Center's General Social Survey (GSS) and the 1990 National Jewish Population Survey (NJPS 1990). In some instances there were direct Jewish identifiers (e.g., the question, "What is your religion?”). In other instances, indirect techniques were employed, such as for the early decades of the $20^{\text {th }}$ century a Yiddish or Hebrew mother tongue or Russian or Russian-Poland birth or parentage.

The decennial census of the Unites States asked for the respondents' occupation for the first time in 1850 . There would be no practical way of identifying Jews in the 1850 Census, since that census and every census since then did not ask religion. Most of the Jews in the United States at that time were born in the U.S. of Sephardic origin or were recent immigrants from Germany. Neither group of Jews could be identified as such in the data that are available. Country of birth was first asked in the Census of 1850 and parents' country of birth was first asked in 1870 (although the question on parents' country of birth was discontinued after the 1970 Census). The first time language was asked was in 1910 with a question on "mother tongue", specified in 1910 as the customary language spoken in the home before immigrating by the respondent or the respondent's parents. A language question of one sort or another has been included in every census since then, most recently regarding a language other than or in additions to English currently spoken in the home, other than just a few words.

\footnotetext{
${ }^{1}$ For studies of Jewish women's labor supply behavior over the course of the $20^{\text {th }}$ century, see Chiswick (1988) and Glenn (1990), and the references therein.
} 
The large scale Russian and Russian-Polish Jewish immigration did not begin until the 1880s. In principle the 1890 Census would be the first census that could be used to develop the occupational distribution of American Jews using Russian origin as an identifier for Jewish immigrants. Unfortunately, the published volumes from this census do not include an occupational distribution by country of birth, and most of the manuscript records from this census were destroyed in a fire (Blake 1996). As a result, a systematic microdata file has not been developed from the 1890 Census. Public use microdata samples had been constructed for all of the Censuses from 1900 through $1990 .^{2}$

Thus, the comparative occupational time series published earlier which was limited to men began with a unique survey, published as Vital Statistics of the Jews of the United States, better known as the Billings Report (Billings1890, Chiswick 2001). This appears to be the only time that the U.S. government conducted a survey exclusively of American Jews. As the objective was to survey in 1890 only Jews living in the U.S. as of 1885, the respondents were predominantly German Jews, both native and foreign born.

The time series ended with the latest data available on a national sample of American Jews, from the National Jewish Population Survey of 1990 (NJPS 1990). The occupational distribution of American Jews age 25 to 64 years was compared with the distribution for adult white men as reported in the 1990 Census. While Jews could not be deleted from the 1990 Census data on adult white men, since they were only 2 percent of white men their inclusion would have little overall effect on the white male occupational distribution.

\footnotetext{
${ }^{2}$ Since the Census Bureau did not create a PUMS file for 1930, the 72 year bar to private access to these data had to expire before a non-governmental agency could create these micro data. A preliminary microdata file became available in 2005.
} 
With the completion of the National Jewish Population Survey of 2000/2001 (NJPS 2000) and the release of the 2000 Census PUMS from the Census Bureau, the year 2000 can now be added to the time series for adult men. Moreover, the increase over time in labor force participation rate among adult women and the sample sizes in the two NJPS surveys permit the computation of the occupational distributions of adult Jewish and white women in 1990 and 2000 in a manner comparable to that of men. Finally the change in the census Bureau's and hence the NJPS's occupational classifications from the 1990 to the 2000 data need to be considered to avoid confounding the effects of changes in occupational classifications with changes over time in occupational distributions.

\section{Occupational Data for 1990 and 2000}

Three types of comparisons can be made on the occupational distribution of Jews in 2000 - at a moment in time with non-Jewish whites, across time with Jews in earlier time periods and by gender, that is, between Jewish men and Jewish women. To as great an extent as possible efforts were taken to maximize comparability with the occupational distributions constructed earlier between Jewish and non-Jewish men. To link the analysis the data are reported here for 1990 as well as 2000 .

Table 1 is comparable to Table 1 in Chiswick (1999) and reports the definitions used to identify Jews in the NJPS 1990 and NJPS 2000, that is, Jewish religion at birth. The Public Use Mirco Data Samples from the 1990 and 2000 Censuses of Population are used to identify adult whites. While Jews cannot be separately identified in the Census, given that they constitute only about 2 percent of the adult white population (and total population) their inclusion has only a minor impact on the white occupational distribution, and if anything, tends to bias downward 
Jewish/non-Jewish differences. As before, the analysis is limited to whites since nearly all Jews report their race as white (97 percent in the NJPS 2000) ${ }^{3}$.

To maximize comparability of the NJPS occupational data with that of the Census, in both 1990 and 2000, the NJPS used the same occupational classifications as did the decennial Census. There were, however, revisions in the occupational classifications between the two Censuses. To try to minimize the effects that this might have on interpreting the trends in Jewish relative to non-Jewish occupational attainment from 1990 to 2000 the following procedure was adopted:

(A) The occupational distributions for Jews and non-Jews were computed for the NJPS 1990 and Census 1990 using the original 1990 occupational classifications,

(B) The occupational distributions for the NJPS 1990 and Census 1990 were recomputed using the new 2000 occupational classifications. This was done using the conversion algorithm made available by the Census Bureau ${ }^{4}$.

(C) The occupational distributions for NJPS 2000 and Census 2000 were computed using the new 2000 occupational classifications.

The difference in the occupational distributions from A to B represent the effects of the change in classifications, while the difference between B and C represents the occupational changes over the decade holding constant the occupational classifications.

\footnotetext{
${ }^{3}$ This is consistent with the racial distribution of Jews in the General Social Survey, 96 percent white non-Hispanic, 1 percent Hispanic, 2 percent black and 1 percent Asian (Smith, 2005, p.287).

${ }^{4}$ The algorithm converts 1990 Census occupation categories into the new 2000 Census codes. The reverse, converting 2000 occupations into their 1990 equivalents cannot be done. See Scopp (2003) and U.S. Bureau of the Census (2003).
} 
Among white males age 25 to 64 years labor force participation rates are very high, 89 percent for Jews and 85 percent for non-Jews. The participation rates are much lower for white women (74 percent and 71 percent, respectively, for Jews and others), in spite of the rapid increase in participation rates for women and the milder decline for men during the course of the $20^{\text {th }}$ century. More so for women than for men, an analysis of their earnings and employment would need to take into account that the participation decision is not random, but rather is selective with regards to various characteristics, including age, health status, child care responsibilities, income of other family members, etc. ${ }^{5}$ The data on occupational status are available only for those who worked shortly before or during the survey period.

\section{Occupational Distribution for Men}

First consider the occupational distribution for males in 1990 under the old and the new categories Panels A and B in Table 2, which is an extension of Table 2 in Chiswick (1999). The reclassification of occupations had very little effect on the distribution for the general population of white men. Clerical workers were largely mapped into office workers. Agriculture (1990 codes) decreased from 3.5 percent, in part because farm owners and managers were reclassified as managerial, leaving only 1.3 percent in farming in 2000 codes. Craft workers, operatives and laborers (40 percent) in 1990 were reclassified as construction, transportation and production workers (39 percent) in the 2000 coding.

More dramatic changes occur among Jewish men with the new classifications Managerial employment in 1990 declines from 18 percent to 16 percent, and professional occupations decrease from 43 percent to 42 percent. The blue collar occupations remain about the same at 9 percent. There were no Jews reported in agricultural occupations in the 1990 NJPS.

\footnotetext{
${ }^{5}$ An econometric analysis of the labor supply decisions of Jewish and non-Jewish women is beyond the scope of this paper, but can be found in Chiswick (1988).
} 
Using the 2000 occupational classifications (Panels B and C in Table 2), there are changes from 1990 to 2000. Managerial employment went up among non-Jews (from 13 to 15 percent), and largely stayed the same among Jews (at about 15 percent $)^{6}$. This represents a historic change as a larger proportion of Jews than of non-Jewish white men were in managerial jobs in all previous points in the time series from 1890 to 1990. The gap between male Jews and non-Jews in the professions continued to grow. The proportion of Jewish men in the professions increased from 42 percent to 53 percent, while the increase among white men in general was from only 19 percent to 20 percent. The proportion of Jewish men in office work declined from 8 percent to 3 percent, with a smaller decline (from 7 to 6 percent) among other men. The proportion of Jews working in the four blue collar occupations (farming, construction, transportation and production) went from 9 percent to 7 percent, while among other men it remained at about 40 percent.

The data on professionals in 1990 and 2000 are decomposed into four categories: Medicine (medical doctors and dentists), Law (lawyers and judges), College and University Teachers, and Other Professional Occupations. The proportion of men in Other Professional Occupations in 1990 was essentially not effected by the change in the occupational classifications (Table 2, Panels A and B). The changes from 1990 to 2000, using the 2000 occupational categories, were more dramatic (Table 2, Panels B and C). The proportion of nonJewish white men in each of the four professional categories showed little change. Among Jews, however, the proportions increased slightly in medicine (from 3 to 5 percent) and law (also from 3 to 5 percent), with the most dramatic increase for Other Professional Occupations (from 32 to

\footnotetext{
${ }^{6}$ The standard errors of proportions are discussed in a note to Tables 1 and 2.
} 
41 percent), whereas the proportion as College and University Teachers declined from 3.3 percent to 1.7 percent.

This decline by about half (by 1.6 percentage points) may reflect, in part, either a real trend, a subtle change in the coding procedures of College and University Teachers or random sampling. A real decline in College and University Teaching among younger Jews is consistent with the age distribution of the respondents in the 1990 NJPS. Of the 28 unweighted male respondents in the 1990 NJPS who were coded as being College and University Teachers, 7 were age 55 or older and would be outside the age range in 2000 . Yet, in 2000 only one of the 17 unweighted male respondents in the College and University Teachers category were age 25 to 34 years of age. The decline in the proportion may also be due to random sampling as the change is not statistically significant.

In summary, while there continued to be an increase in the occupational attainment for all white men from 1990 to 2000 (from 33 percent professional and managerial to 35 percent), the level was higher and the increase greater among Jewish men (from 59 percent to 68 percent). Self-employment patterns, however, continue to show some convergence. ${ }^{7}$ Self employment among all men remained stable at 14 percent, but among Jews it declined sharply from 27 percent to 23 percent, continuing a long-term trend. This also continues the trend of Jewish managers and professionals being increasingly salaried rather than self-employed. IV. Occupational Distribution for Women

\footnotetext{
${ }^{7}$ The self-employed includes those who are self-employed in incorporated and unincorporated businesses, as well as the very small number reported as unpaid family workers. The selfemployed can in principle be in any occupation, but most are in professional and managerial occupations.
} 
Table 3 reports the occupational distributions in 1990 and 2000 for Jewish and nonJewish women. ${ }^{8}$ Jewish women experienced a dramatic increase in their occupational attainment from 1990 to 2000, much more so than did non-Jewish women.

Panels A and B in Table 3 compare the occupational distributions for Jewish and other women in 1990 using the original 1990 occupational categories and the redefined occupational codes. The data show that the change in definitions resulted in a small decline in the proportion of Jewish women in managerial occupations (from 15.2 percent to 14.0 percent) and no change in professional (42 percent) occupations, with essentially no change among the other women.

Panels B and C in Table 3 report the occupational distributions in 1990 and 2000 using the 2000 occupational categories. Managerial employment increased among Jewish women from 14 to 16 percent but remained at 11 percent among non- Jewish women over the decade. The proportion of Jewish women employed in professional occupations increased from 42 percent to 51 percent. The level and rate of increase was much greater among Jewish women than among non- Jewish women (an increase for the latter from 24 percent to 28 percent professional). Jewish women experienced a dramatic shift over the decade out of clerical/office work (from 25 percent in 1990 to 12 percent in 2000). Their employment increased in sales from 10 to 13 percent but showed little change in service (about 5 percent), and the four blue collar occupations (about 3 percent). Non- Jewish women were less likely to be in sales jobs (11 percent), but were far more likely to be in service (15 percent) and blue collar jobs (9 percent) in 2000, with little change for the non-Jewish women over the decade.

Within the professional occupations Jewish women are more likely than non- Jewish women to be in three of the four subcategories, with little difference in the college and university

\footnotetext{
${ }^{8}$ These data are, of course, reported only for women who worked and reported an occupation.
} 
teaching subcategory. They are, however, less likely than Jewish men to be in medicine, law and college and university teaching, but are more likely to be in other professions (including other teaching and social work), 45 percent for Jewish women and 41 percent for Jewish men.

Among both Jews and non- Jews there is little gender difference in the proportion of workers in the high skilled occupations, managerial and professional employment. Among employed Jews, 67 percent of the women and 68 percent of the men were in these occupations, among non-Jews this was the case for 39 percent of the women and 35 percent of the men. Thus, the differences in the proportion in high level occupations by religion are large, but the differences by gender within religions are small.

Self-employment (including unpaid family work) among Jewish women declined from 14 percent to in 1990 to 11 percent in 2000, but remained higher than the stable level of 9 percent among non- Jewish women. Yet, the self-employment of Jewish women remained at about half the rate of Jewish men (23 percent in 2000).

\section{Summary and Conclusions}

This paper has analyzed the occupational distributions of adult white Jewish and nonJewish men and women in 1990 and 2000, using the U.S. Censuses of Population and the National Jewish Population Surveys conducted in those years. Adjustments are made to the data to account for the changes in the occupational classifications between 1990 and 2000, and the changes due to the reclassifications are shown to be minor.

Jewish men had a greater proportion in managerial and professional occupations in 1990 (62 percent) compared to other men (32 percent), and the gap increased by 2000 (68 percent for Jews and 35 percent among non-Jews). The share of male Jewish employment in sales remained constant (about 18 percent), but declined in office, service and blue collar work. 
Managerial employment declined over the decade among Jewish men from 17 percent to 15 percent and self employment continued the long term decline (from 27 to 23 percent over the decade). This reflects the greater tendency for Jewish managers and professionals to be salaried workers rather than self-employed.

Jewish women also had a greater proportion in managerial and professional occupations in 1990 than other women (56 percent compared to 34 percent) and a greater increase over the decade (67 percent for Jews compared to 39 percent for other women in 2000). Jewish women experienced a large decline in office work (from 25 percent in 1990 to 12 percent in 2000), with little change in the other occupational categories.

Self employment also declined among Jewish women from 14 percent to 11 percent, but remained at half of the rate for Jewish men (23 percent). Yet it exceeded the self-employment rate among other women (9 percent).

Overall, the proportion in high level occupations (managerial and professional) in 2000 are about the same for men and women who are Jewish (about 68 percent), and are about the same for white men and women who are not Jewish (about 35 to 39 percent). The gender differences are small, the religion differences are large. Moreover, the share of Jews in high level occupations continued to increase at a more rapid rate over the 1990s, especially among professional occupations, increasing the gap. This change and the decline in the self-employment differential reflect an increased tendency among Jewish men and women in high level occupations to be salaried workers rather then self-employed.

The implications of the continued growth in high level employment as salaried managers and professionals may be for reaching and warrant further study. 


\section{$\underline{\text { References }}$}

Blake, Kellee (1996) "First in the Path of the Fireman: The Fate of the 1890 Population Census” Prologue, Spring, pp 64-81

Billings, John R. (1890) Vital Statistics of the Jews of the United States, Census Bulletin, No. 19, Washington, DC, December 30, 1890.

Chiswick, Barry R. (1988) "Labor Supply and Investment in Child Quality: A Study of Jewish and Non-Jewish Women” Contemporary Jewry, 9, Fall, pp. 35-61.

Chiswick, Barry R. (1999) “The Occupational Attainment and Earnings of American Jewry, 1890-1990” Contemporary Jewry 20, pp 68-98.

Chiswick, Barry R. (2001) "The Billings Report and the Occupational Attainment of American Jewry” Shofar: An Interdisciplinary Journal of Jewish Studies, 19(2), Winter, pp.5375.

Glenn, Susan A. (1990) Daughters of the Shtetl: Life and Labor in the Immigrant Generation. Ithaca: Cornell University Press.

Marcus, Jacob Rader (1995) The American Jew, 1585-1990: A History, Brooklyn: Carlson Publishing.

North America Jewish Data Bank (1991) National Jewish Population Survey, 1990, New York: Graduate School and University Center, City University of New York

North American Jewish Data Bank (2002) National Jewish Population Survey, $\underline{2000 / 2001}$ New York

National Jewish Population Survey 2000-01, Strength, Challenge and Diversity in the American Jewish Population, New York: United Jewish Communities, September 2003.

Scopp, Thomas S. under special contract with the U.S. Census Bureau (2003) "The Relationship Between The 1990 Census and Census 2000 Industry and Occupation Classification Systems, Technical Paper \#65” October 30, 2003, available at http://www.census.gov/hhes/www/ioindex/tp65 report.html

Smith, Tom W. (2005) Jewish Distinctiveness in America: A Statistical Portrait New York: American Jewish Committee.

U.S. Bureau of the Census (1993) 1990 Census of Population, Public Use Microdata Sample (1/100Sample), Washington, DC

U.S. Bureau of the Census (2003) 2000 Census of Population, Public Use Microdata Sample (1/100 Sample), Washington, DC 
U.S. Bureau of the Census (2003) "Template for Converting 1990 Census STF-3 Occupation Categories to Census 2000 SF-3 Occupation Categories” available at http://www.census.gov/hhes/www/ioindex/occross menu.html. 
Table 1 - Summary Characteristics of Data for Analysis of Adult White Men and Women, Jews and non-Jews, 1990 - $2000 .{ }^{\mathrm{i}}$

\begin{tabular}{|c|c|c|c|c|}
\hline$\underline{\text { Period }}$ & Data Set & Identification of Jews & Comments & Population $^{\mathrm{j}}$ \\
\hline 1990 & $\begin{array}{l}\text { National Jewish } \\
\text { Population } \\
\text { Survey, } 1990 \\
1990 \text { Census of } \\
\text { Population, PUMS, } \\
\text { 1/100 Sample. }\end{array}$ & $\begin{array}{l}\text { Religion at birth } \\
\text { in NJPS. }\end{array}$ & $\begin{array}{l}\text { Males and } \\
\text { Females, } \\
\text { age 25-64 } \\
\text { years. } \\
\text { Respondents } \\
\text { only in NJPS }\end{array}$ & $\begin{array}{l}5.5 \text { million Jews } \\
2.2 \text { percent of } \\
\text { population } \\
\text { (“core” Jews) }\end{array}$ \\
\hline 2000 & $\begin{array}{l}\text { National Jewish } \\
\text { Population Survey } \\
\text { 2000/2001 } \\
\text { 2000 Census of } \\
\text { Population, PUMS, } \\
\text { 1/100 Sample. }\end{array}$ & $\begin{array}{l}\text { Religion at birth } \\
\text { in NJPS. }\end{array}$ & $\begin{array}{l}\text { Males and } \\
\text { Females, } \\
\text { age 25-64 } \\
\text { years. } \\
\text { Respondents } \\
\text { only in NJPS }\end{array}$ & $\begin{array}{l}5.2 \text { million Jews } \\
1.9 \text { percent of } \\
\text { population } \\
\text { (“core” Jews) }\end{array}$ \\
\hline
\end{tabular}

\footnotetext{
i Jews included among non-Jews.

j The population estimate for Jews is based on a slightly different definition of who is Jewish than the definition used to construct the occupational distributions. Comparable definitions of who is a Jew in the 1990 and 2000/2001 NJPS. Data on number of Jews from National Jewish Population Survey 2000-01, Strength, Challenge and Diversity in the American Jewish Population, New York: United Jewish Communities, September 2003, Table 1
} 
Table 2. Occupational Distribution and Self-Employment Status for Adult Jewish and White Men, 1990 - 2000 (Percent)

\begin{tabular}{|c|c|c|}
\hline Occupation Category (1990 Classification) & NJPS 1990 & Census 1990 \\
\hline Managerial & 18.29 & 13.25 \\
\hline Professional \& Technical and Kindred Workers & 43.33 & 19.20 \\
\hline Med. (MD, DDS) & 3.40 & 1.00 \\
\hline Law & 2.89 & 1.08 \\
\hline Col \& U Teacher & 3.75 & 0.76 \\
\hline Other Professional Occupations & 33.29 & 16.36 \\
\hline Sales & 17.94 & 11.16 \\
\hline Clerical & 7.04 & 5.93 \\
\hline Service & 4.52 & 7.39 \\
\hline Agriculture & 0.00 & 3.45 \\
\hline Craft & 6.20 & 20.89 \\
\hline Operatives & 1.73 & 16.14 \\
\hline Labor & 0.96 & 2.61 \\
\hline Total & 100.0 & 100.0 \\
\hline Self-Employed (Percent) & 26.84 & 14.06 \\
\hline Sample Size & 683 & 488,970 \\
\hline Occupation Category (2000 Classification) & NJPS 1990 & Census 1990 \\
\hline Managerial & 16.53 & 13.14 \\
\hline Professional & 42.43 & 18.98 \\
\hline Med. (MD, DDS) & 3.40 & 1.00 \\
\hline Law & 2.89 & 1.08 \\
\hline Col \& U Teacher & 3.75 & 0.76 \\
\hline Other Professional Occupations & 32.39 & 16.14 \\
\hline Sales & 18.32 & 11.45 \\
\hline Office & 7.89 & 7.13 \\
\hline Service & 5.43 & 8.85 \\
\hline Farming & 0.00 & 1.26 \\
\hline Construction & 4.79 & 16.55 \\
\hline Transportation & 1.75 & 13.35 \\
\hline Production & 2.83 & 9.28 \\
\hline Total & 100.0 & 100.0 \\
\hline Self-Employed (Percent) & 26.84 & 14.06 \\
\hline Sample Size & 683 & 488,970 \\
\hline Occupation Category (2000 Classification) & NJPS 2000 & Census 2000 \\
\hline Managerial & 14.78 & 15.09 \\
\hline Professional & 52.99 & 19.74 \\
\hline Med. (MD, DDS) & 4.76 & 0.93 \\
\hline Law & 5.31 & 1.10 \\
\hline Col \& U Teacher & 1.88 & 0.93 \\
\hline Other Professional Occupations & 41.04 & 16.78 \\
\hline Sales & 18.50 & 10.39 \\
\hline Office & 3.08 & 6.04 \\
\hline Service & 3.85 & 9.13 \\
\hline Farming & 0.22 & 0.89 \\
\hline Construction & 2.76 & 18.72 \\
\hline Transportation & 2.15 & 8.99 \\
\hline Production & 1.67 & 11.01 \\
\hline Total & 100.0 & 100.0 \\
\hline Self-Employed (Percent) & 23.23 & 14.02 \\
\hline Sample Size & 1,062 & 529,956 \\
\hline
\end{tabular}


Table 3. Occupational Distribution and Self-Employment Status for Adult Jewish and White Women, 1990 - 2000 (Percent)

\begin{tabular}{|c|c|c|}
\hline Occupation Category (1990 Classification) & NJPS 1990 & Census 1990 \\
\hline Managerial & 15.16 & 10.53 \\
\hline Professional \& Technical and Kindred Workers & 42.42 & 23.60 \\
\hline Med. (MD, DDS) & 0.43 & 0.25 \\
\hline Law & 2.32 & 0.41 \\
\hline Col \& U Teacher & 2.26 & 0.64 \\
\hline Other Professional Occupations & 37.41 & 22.30 \\
\hline Sales & 9.35 & 11.76 \\
\hline Clerical & 24.84 & 27.43 \\
\hline Service & 5.07 & 14.74 \\
\hline Agriculture & 0.00 & 0.99 \\
\hline Craft & 2.36 & 2.41 \\
\hline Operatives & 0.29 & 7.98 \\
\hline Labor & 0.51 & 0.55 \\
\hline Total & 100.0 & 100.0 \\
\hline Self-Employed (Percent) & 14.02 & 8.55 \\
\hline Sample Size & 641 & 438,355 \\
\hline Occupation Category (2000 Classification) & NJPS 1990 & Census 1990 \\
\hline Managerial & 14.00 & 10.23 \\
\hline Professional & 41.83 & 23.69 \\
\hline Med. (MD, DDS) & 0.43 & 0.25 \\
\hline Law & 2.32 & 0.41 \\
\hline Col \& U Teacher & 2.26 & 0.64 \\
\hline Other Professional Occupations & 36.82 & 22.39 \\
\hline Sales & 9.83 & 12.14 \\
\hline Office & 24.70 & 27.16 \\
\hline Service & 5.93 & 15.43 \\
\hline Farming & 0.00 & 0.37 \\
\hline Construction & 1.89 & 2.32 \\
\hline Transportation & 0.81 & 2.10 \\
\hline Production & 0.99 & 6.60 \\
\hline Total & 100.0 & 100.0 \\
\hline Self-Employed (Percent) & 14.02 & 8.55 \\
\hline Sample Size & 641 & 438,355 \\
\hline Occupation Category (2000 Classification) & NJPS 2000 & Census 2000 \\
\hline Managerial & 15.91 & 10.96 \\
\hline Professional & 51.37 & 28.47 \\
\hline Med. (MD, DDS) & 2.07 & 0.36 \\
\hline Law & 3.33 & 0.52 \\
\hline Col \& U Teacher & 0.83 & 0.92 \\
\hline Other Professional Occupations & 45.14 & 26.67 \\
\hline Sales & 12.89 & 11.10 \\
\hline Office & 12.12 & 25.06 \\
\hline Service & 4.74 & 15.41 \\
\hline Farming & 0.00 & 0.32 \\
\hline Construction & 1.68 & 0.84 \\
\hline Transportation & 0.59 & 2.03 \\
\hline Production & 0.34 & 5.80 \\
\hline Total & 100.0 & 100.0 \\
\hline Self-Employed (Percent) & 11.27 & 8.62 \\
\hline Sample Size & 1,218 & 488,113 \\
\hline
\end{tabular}


Notes to Tables 2 and 3.

Jews by religion at birth and white persons age 25 to 64 who reported an occupation. Selfemployed includes those in incorporated and unincorporated businesses and unpaid family workers. Farm owners and farm managers are included in Agriculture in the 1990 occupational classifications but in Managerial in the 2000 classifications. For the 2000 codes farmers are hired farm workers who are not farm managers. Military officers are included in Professional occupations while enlisted personnel and rank not specified are in Operative (1990 classification) and Production (2000 classification) jobs. Sum may not total 100.0 due to rounding.

Reasons for Loss of Observations

\begin{tabular}{lrrrr}
\hline & \multicolumn{2}{c}{1990 NJPS } & \multicolumn{2}{c}{ 2000 NJPS } \\
\hline & Males & Females & Males & Females \\
\hline Number of Respondents & 1185 & 1256 & 2281 & 2867 \\
Loss of Observations: & & & & \\
$\quad$ No Occupation & 49 & 60 & 631 & 1024 \\
$\quad$ Not Born Jewish & 231 & 310 & 309 & 334 \\
Under Age 25 & 65 & 61 & 141 & 156 \\
Over Age 64 & 157 & 179 & 134 & 123 \\
$\quad$ Age Not Reported & 0 & 5 & 4 & 12 \\
\hline Sample Size & 683 & 641 & 1062 & 1218 \\
\hline
\end{tabular}

The standard error of the estimate for a_proportion is s.e. $=\sqrt{ }$ pq/N. The largest standard error is when $\mathrm{p}=.5$, and for a sample of approximately 650 this is approximately 0.020 , and for a sample of approximately 1,100 it is approximately 0.0156 . The census samples are so large that the standard errors are approximately zero for all practical purposes (s.e. $=0.0007)$.

The standard error for the difference in proportions from two independent samples is s.e. $=\sqrt{ }\left(\mathrm{p}_{1} \mathrm{q}_{1} / \mathrm{N}_{1}\right)+\left(\mathrm{p}_{2} \mathrm{q}_{2} / \mathrm{N}_{2}\right)$, which at a maximum for two samples is s.e. $=\sqrt{ }(.5)^{2} / \mathrm{N}_{1}+(.5)^{2} / \mathrm{N}_{2}=.5 \sqrt{ } 1 / \mathrm{N}_{1}+1 / \mathrm{N}_{2}$. 


\section{Appendix}

Table A-1. NJPS 1990 Occupation Distribution

Data source: NJPS 1990.

Code: Based on 1990 census occupation codes.

Sample: Adult male Jews age between 25 and 64 who reported occupation and whose religion born is Jewish ${ }^{1}$.

NJPS 1990

\begin{tabular}{lr}
\hline Occupation Category based on Census 1990 occupation codes & Percentage \\
\hline Managerial (201-246, exclude 213, 215) & $18.29^{3}$ \\
Professional \& Tech (001-197, 213, 215) & 43.33 \\
$\quad$ Med. (MD, DDS(062, 065)) & 3.40 \\
$\quad$ Law (030, 031) & 2.89 \\
$\quad$ Col \& U Teacher (102-140) & 3.75 \\
$\quad$ Other Professional Occupations & 33.29 \\
Sales (260-280) & 17.94 \\
Clerical (301-395) & 7.04 \\
Service (901-984) & 4.52 \\
Agriculture (801-824) & 0.00 \\
Craft (401-575) & 6.20 \\
Operatives (580-715) & 1.73 \\
Labor (740-785) $^{\text {Salf-Employed }}{ }^{4}$ (percent) & 0.96 \\
\hline
\end{tabular}

Notes:

1. Religion born is Jewish if the answer to question 19 in NJPS 1990 questionnaire is 1.

2. Please refer to the answer to question 48 in NJPS 1990 questionnaire for the specific meaning of each occupation code. 213 (construction inspectors, public administration), 215 (inspectors, except construction, public administration).

3. All the numbers are weighted using population weight in NJPS 1990 data set (variable 'popwgt').

4. A person is self-employed if the answer to question 50 is " 2 " (self-employed) or " 4 " (in a family business for no pay). 
Table A-2. NJPS 1990 Occupation Distribution

Data source: NJPS 1990.

Code: Based on 1990 census occupation codes.

Sample: Adult female Jews age between 25 and 64 who reported occupation and whose religion born is Jewish ${ }^{1}$.

NJPS 1990

\begin{tabular}{lr}
\hline Occupation Category based on Census 1990 occupation codes & Percentage \\
\hline Managerial (201-246, exclude 213, 215) & $15.16^{3}$ \\
Professional \& Tech (001-197, 213, 215) & 42.42 \\
$\quad$ Med. (MD, DDS(062, 065)) & 0.43 \\
$\quad$ Law (030, 031) & 2.32 \\
$\quad$ Col \& U Teacher (102-140) & 2.26 \\
$\quad$ Other Professional Occupations & 37.41 \\
Sales (260-280) & 9.35 \\
Clerical (301-395) & 24.84 \\
Service (901-984) & 5.07 \\
Agriculture (801-824) & 0.00 \\
Craft (401-575) & 2.36 \\
Operatives (580-715) & 0.29 \\
Labor (740-785) $^{\text {Self-Employed }}{ }^{4}$ (percent) & 0.51 \\
\hline
\end{tabular}

Notes:

1. Religion born is Jewish if the answer to question 19 in NJPS 1990 questionnaire is 1 .

2. Please refer to the answer to question 48 in NJPS 1990 questionnaire for the specific meaning of each occupation code. 213 (construction inspectors, public administration), 215 (inspectors, except construction, public administration).

3. All the numbers are weighted using population weight in NJPS 1990 data set (variable 'popwgt').

4. A person is self-employed if the answer to question 50 is " 2 " (self-employed) or " 4 " (in a family business for no pay). 
Table B-1. Census 1990 Occupation Distribution

Data source: Census 1990 PUMS one percent sample downloaded from ICPSR.

Code: Based on 1990 census occupation codes.

Sample: Adult white male age between 25 and 64 who reported occupation.

Census 1990

Occupation Category based on Census 1990 occupation codes $\quad$ Percentage

Managerial (000-042, exclude 023, 024, 026, 035, 036) ${ }^{1} \quad 13.25^{2}$

Professional \& Tech (043-242, plus 023, 024, 026, 035, 036, 903) 19.20

Med. (MD, DDS $(084,085)) \quad 1.00$

$\begin{array}{ll}\text { Law }(178,179) & 1.08\end{array}$

Col \& U Teacher (113-154) $\quad 0.76$

Other Professional Occupations 16.36

Sales (243-302) 11.16

Clerical (303-402) $\quad 5.93$

$\begin{array}{ll}\text { Service (403-472) } & 7.39\end{array}$

Agriculture (473-502) $\quad 3.45$

$\begin{array}{ll}\text { Craft (503-702) } & 20.89\end{array}$

Operatives (703-888, exclude 869, plus 904, 905) 16.14

\begin{tabular}{lr} 
Labor (889-902, plus 869) & 2.61 \\
\hline
\end{tabular}

\begin{tabular}{lr}
\hline Self-Employed $^{3}$ (percent) & 14.06 \\
\hline
\end{tabular}

Notes:

1. Here is a partial list for the occupation codes used in this table, for a complete list, please refer to Census 1990 occupation list. 23 (accountants), 24 (underwriters), 26

(management analysts), 35 (construction inspectors), 36 (inspectors and compliance officers), 869 (construction labors), 903 (military occupation: commissioned officers and warrant officers), 904 (military occupation: non-commissioned officers and other enlisted personnel), 905 (military occupation, rank not specified).

2. All the numbers are weighted using personal weights (variable 'pwgt1').

3. Self-employed include 'Self-employed in unincorporated business or company'; Selfemployed in incorporated business or company'; Unpaid family worker'. 
Table B-2. Census 1990 Occupation Distribution

Data source: Census 1990 PUMS one percent sample downloaded from ICPSR.

Code: Based on 1990 census occupation codes.

Sample: Adult white female age between 25 and 64 who reported occupation.

Census 1990

Occupation Category based on Census 1990 occupation codes $\quad$ Percentage

Managerial (000-042, exclude 023, 024, 026, 035, 036) ${ }^{1} \quad 10.53^{2}$

Professional \& Tech (043-242, plus 023, 024, 026, 035, 036, 903) 23.60

Med. (MD, DDS $(084,085)) \quad 0.25$

$\begin{array}{ll}\text { Law }(178,179) & 0.41\end{array}$

Col \& U Teacher (113-154) $\quad 0.64$

Other Professional Occupations $\quad 22.30$

$\begin{array}{ll}\text { Sales (243-302) } & 11.76\end{array}$

$\begin{array}{ll}\text { Clerical (303-402) } & 27.43\end{array}$

$\begin{array}{lr}\text { Service (403-472) } & 14.74\end{array}$

$\begin{array}{ll}\text { Agriculture (473-502) } & 0.99\end{array}$

$\begin{array}{ll}\text { Craft (503-702) } & 2.41\end{array}$

Operatives (703-888, exclude 869, plus 904, 905) 7.98

\begin{tabular}{lr} 
Labor (889-902, plus 869) & 0.55 \\
\hline
\end{tabular}

\begin{tabular}{lr}
\hline Self-Employed $^{3}$ (percent) & 8.55 \\
\hline
\end{tabular}

Notes:

1. Here is a partial list for the occupation codes used in this table, for a complete list, please refer to Census 1990 occupation list. 23 (accountants), 24 (underwriters), 26

(management analysts), 35 (construction inspectors), 36 (inspectors and compliance officers), 869 (construction labors), 903 (military occupation: commissioned officers and warrant officers), 904 (military occupation: non-commissioned officers and other enlisted personnel), 905 (military occupation, rank not specified).

2. All the numbers are weighted using personal weights (variable 'pwgt1').

3. Self-employed include 'Self-employed in unincorporated business or company'; Selfemployed in incorporated business or company'; Unpaid family worker'. 
Table C-1. NJPS 1990 Occupation Distribution

Data source: NJPS 1990.

Code: Based on 2000 census occupation codes ${ }^{1}$.

Sample: Adult male Jews age between 25 and 64 who reported occupation and whose religion born is Jewish².

NJPS 1990

\begin{tabular}{lr}
\hline Occupation Category based on Census 2000 occupation codes & Percentage \\
\hline Managerial (001-099) & 16.53 \\
Professional (100-359) & 42.43 \\
$\quad$ Med. (MD, DDS(301, 306)) & 3.40 \\
$\quad$ Law (210, 211) & 2.89 \\
$\quad$ Col \& U Teacher (220) & 3.75 \\
Other Professional Occupations & 32.39 \\
Sales (470-499) & 18.32 \\
Office (500-599) & 7.89 \\
Service (360-469) & 5.43 \\
Farming (600-619) & 0.00 \\
Construction (620-769) & 4.79 \\
Transportation (900-979) & 1.75 \\
Production (770-899) & 2.83 \\
\hline Self-Employed & (percent) \\
\hline
\end{tabular}

Notes:

1. The Census 2000 industry and occupation classifications were completely revised compared to 1990. They are now based on the 1997 NAICS (North American Industry Classification System) and the 2000 SOC (Standard Occupational Classification) coding structures. The 1990 system was based on the 1987 SIC (Standard Industrial Classification Manual) and the 1980 SOC (Standard Occupational Classification Manual). In order to compare the change of occupation distribution over time, we converted the Census 1990 occupation category into Census 2000 occupation category based on the published crosswalks from census website. The crosswalk we used is "The Relationship Between the 1990 Census and Census 2000 Industry and Occupation Classification Systems, Technical Paper \#65"

(http://www.census.gov/hhes/www/ioindex/tp65_report.html) and "Occupation Table Crosswalks for Comparing 1990 to 2000 Census Data”

(http://www.census.gov/hhes/www/ioindex/occcross_menu.html). One caveat about using the template provided by the census website is that the conversion factors in the template is based on the employed persons age 16 and over in Census 1990 data. Those conversion factors may not be appropriate when applied to Jews. For example, according to the template, among those employed persons age 16 and over whose reported occupation belongs to Farming, Forestry \& Fishing occupations in census 1990 coding structure, $35 \%$ is reclassified into management occupation category in census 2000 
coding structure; $29 \%$ is reclassified into service occupation category; $36 \%$ is reclassified into Farming, Forestry \& Fishing occupation category; and the rest is reclassified into transportation occupation category. It is very likely that those conversion factors (percentages) will be different for Jews than the rest of the population.

2. Religion born is Jewish if the answer to question 19 in NJPS 1990 questionnaire is 1.

3. A person is self-employed if the answer to question 50 is " 2 " (self-employed) or " 4 " (in a family business for no pay).

Table C-2. NJPS 1990 Occupation Distribution

Data source: NJPS 1990.

Code: Based on 2000 census occupation codes.

Sample: Adult female Jews age between 25 and 64 who reported occupation and whose religion born is Jewish².

NJPS 1990

Occupation Category based on Census 2000 occupation codes

Managerial (001-099)

Percentage

Professional (100-359)

14.00

41.83

Med. (MD, DDS(301, 306))

0.43

Law $(210,211)$

2.32

Col \& U Teacher (220)

2.26

Other Professional Occupations

36.82

Sales (470-499)

9.83

Office (500-599)

24.70

Service (360-469)

5.93

Farming (600-619)

0.00

Construction (620-769)

1.89

Transportation (900-979)

0.81

Production (770-899)

0.99

Self-Employed (percent)

14.02


Table D-1. Census 1990 Occupation Distribution

Data source: Census 1990 PUMS one percent sample downloaded from ICPSR.

Code: Based on 2000 census occupation codes.

Sample: Adult white male age between 25 and 64 who reported occupation.

Census 1990

\begin{tabular}{lr}
\hline Occupation Category based on Census 2000 occupation codes & Percentage \\
\hline Managerial (001-099) & 13.14 \\
Professional (100-359) & 18.98 \\
$\quad$ Med. (MD, DDS(301, 306)) & 1.00 \\
$\quad$ Law (210, 211) & 1.08 \\
$\quad$ Col \& U Teacher (220) & 0.76 \\
$\quad$ Other Professional Occupations & 16.14 \\
Sales (470-499) & 11.45 \\
Office (500-599) & 7.13 \\
Service (360-469) & 8.85 \\
Farming (600-619) & 1.26 \\
Construction (620-769) & 16.55 \\
Transportation (900-979) & 13.35 \\
Production (770-899) & 9.28 \\
\hline Self-Employed ${ }^{2}$ (percent) & 14.06 \\
\hline
\end{tabular}

Notes:

1. The Census 2000 industry and occupation classifications were completely revised compared to 1990. They are now based on the 1997 NAICS (North American Industry Classification System) and the 2000 SOC (Standard Occupational Classification) coding structures. The 1990 system was based on the 1987 SIC (Standard Industrial Classification Manual) and the 1980 SOC (Standard Occupational Classification Manual). In order to compare the change of occupation distribution over time, we converted the Census 1990 occupation category into Census 2000 occupation category based on the published crosswalks from census website. The crosswalk we used is "The Relationship Between the 1990 Census and Census 2000 Industry and Occupation Classification Systems, Technical Paper \#65"

(http://www.census.gov/hhes/www/ioindex/tp65_report.html) and "Occupation Table Crosswalks for Comparing 1990 to 2000 Census Data” (http://www.census.gov/hhes/www/ioindex/occcross_menu.html). One caveat about using the template provided by the census website is that the conversion factors in the template is based on the employed persons age 16 and over in Census 1990 data. Those conversion factors may not be appropriate when applied to Jews.

2. Self-employed include 'Self-employed in unincorporated business or company'; Selfemployed in incorporated business or company'; Unpaid family worker'. 
Table D-2. Census 1990 Occupation Distribution

Data source: Census 1990 PUMS one percent sample downloaded from ICPSR.

Code: Based on 2000 census occupation codes.

Sample: Adult white female age between 25 and 64 who reported occupation.

Census 1990

\begin{tabular}{lr}
\hline Occupation Category based on Census 2000 occupation codes & Percentage \\
\hline Managerial (001-099) & 10.23 \\
Professional (100-359) & 23.69 \\
$\quad$ Med. (MD, DDS(301, 306)) & 0.25 \\
$\quad$ Law (210, 211) & 0.41 \\
$\quad$ Col \& U Teacher (220) & 0.64 \\
$\quad$ Other Professional Occupations & 22.39 \\
Sales (470-499) & 12.14 \\
Office (500-599) & 27.16 \\
Service (360-469) & 15.43 \\
Farming (600-619) & 0.37 \\
Construction (620-769) & 2.32 \\
Transportation (900-979) & 2.10 \\
Production (770-899) & 6.60 \\
Self-Employed $^{2}$ (percent) & 8.55 \\
\hline
\end{tabular}

Notes:

1. The Census 2000 industry and occupation classifications were completely revised compared to 1990. They are now based on the 1997 NAICS (North American Industry Classification System) and the 2000 SOC (Standard Occupational Classification) coding structures. The 1990 system was based on the 1987 SIC (Standard Industrial Classification Manual) and the 1980 SOC (Standard Occupational Classification Manual). In order to compare the change of occupation distribution over time, we converted the Census 1990 occupation category into Census 2000 occupation category based on the published crosswalks from census website. The crosswalk we used is "The Relationship Between the 1990 Census and Census 2000 Industry and Occupation Classification Systems, Technical Paper \#65" (http://www.census.gov/hhes/www/ioindex/tp65_report.html) and "Occupation Table Crosswalks for Comparing 1990 to 2000 Census Data” (http://www.census.gov/hhes/www/ioindex/occcross_menu.html). One caveat about using the template provided by the census website is that the conversion factors in the template is based on the employed persons age 16 and over in Census 1990 data. Those conversion factors may not be appropriate when applied to Jews.

2. Self-employed include 'Self-employed in unincorporated business or company'; Selfemployed in incorporated business or company'; Unpaid family worker'. 
Table E-1. NJPS 2000 Occupation Distribution

Data source: NJPS 2000.

Code: Based on 2000 census occupation codes.

Sample: Adult male Jews age between 25 and 64 who reported occupation and whose religion born is Jewish ${ }^{1}$

NJPS 2000

\begin{tabular}{lr}
\hline Occupation Category based on Census 2000 occupation codes & Percentage \\
\hline Managerial (1-52, exclude 34, 38, 41, 47, 511, 515) & $14.78^{3}$ \\
Professional (53-175, plus 34, 38, 41, 47, 508, 510, 512) & 52.99 \\
$\quad$ Med. (MD, DDS(148, 152)) & 4.76 \\
$\quad$ Law (113, 114) & 5.31 \\
$\quad$ Col \& U Teacher (117) & 1.88 \\
$\quad$ Other Professional Occupations & 41.04 \\
Sales (238-255) & 18.50 \\
Office (256-306) & 3.08 \\
Service (176-237, 513, 514) & 3.85 \\
Farming (307-315) & 0.22 \\
Construction (316-390) & 2.76 \\
Transportation (472-505) & 2.15 \\
Production (391-471, plus 509) & 1.67 \\
\hline Self-Employed ${ }^{4}$ (percent) & 23.23 \\
\hline
\end{tabular}

Notes:

1. Religion born is Jewish if the person is Jewish by religion/ethnicity and at least one of parents is Jew.

2. Here is a partial list for the occupation codes used in this table, for a complete list, please refer to the answer to question Q289_A in NJPS 2000 questionnaire. 34 (compliance officers), 38 (management analysts), 41 (accountants and auditors), 47 (insurance underwriters), 508 (military enlisted tactical operations and air/weapons specialists and crew members), 509 (military occupation, rank not specified), 510 (computers no further information), 511 (executives no further information), 512 (professional no further information), 513 (supervisor no further information), 514 (technician no further information), 515 (self-employed no further information).

3. All numbers are weighted using personal weights. (variable 'wt3presp').

4. A person is self-employed if the answer to question q293_a is "2" (self-employed) or "4" (in a family business without pay). 
Table E-2. NJPS 2000 Occupation Distribution

Data source: NJPS 2000.

Code: Based on 2000 census occupation codes.

Sample: Adult female Jews age between 25 and 64 who reported occupation and whose religion born is Jewish ${ }^{1}$

NJPS 2000

\begin{tabular}{lr}
\hline Occupation Category based on Census 2000 occupation codes & Percentage \\
\hline Managerial (1-52, exclude 34, 38, 41, 47, 511, 515) & $15.91^{3}$ \\
Professional (53-175, plus 34, 38, 41, 47, 508, 510, 512) & 51.37 \\
$\quad$ Med. (MD, DDS(148, 152)) & 2.07 \\
$\quad$ Law (113, 114) & 3.33 \\
$\quad$ Col \& U Teacher (117) & 0.83 \\
$\quad$ Other Professional Occupations & 45.14 \\
Sales (238-255) & 12.89 \\
Office (256-306) & 12.12 \\
Service (176-237, 513, 514) & 4.74 \\
Farming (307-315) & 0.00 \\
Construction (316-390) & 1.68 \\
Transportation (472-505) & 0.59 \\
Production (391-471, plus 509) & 0.34 \\
\hline Self-Employed ${ }^{4}$ (percent) & 11.27 \\
\hline
\end{tabular}

Notes:

1. Religion born is Jewish if the person is Jewish by religion/ethnicity and at least one of parents is Jew.

2. Here is a partial list for the occupation codes used in this table, for a complete list, please refer to the answer to question Q289_A in NJPS 2000 questionnaire. 34 (compliance officers), 38 (management analysts), 41 (accountants and auditors), 47 (insurance underwriters), 508 (military enlisted tactical operations and air/weapons specialists and crew members), 509 (military occupation, rank not specified), 510 (computers no further information), 511 (executives no further information), 512 (professional no further information), 513 (supervisor no further information), 514 (technician no further information), 515 (self-employed no further information).

3. All numbers are weighted using personal weights. (variable 'wt3presp').

4. A person is self-employed if the answer to question q293_a is "2" (self-employed) or "4" (in a family business without pay). 
Table F-1. Census 2000 Occupation Distribution

Data source: Census 2000 PUMS one percent sample downloaded from ICPSR.

Code: Based on 2000 census occupation codes.

Sample: Adult white male age between 25 and 64 who reported occupation.

Census 2000

Occupation Category based on Census 2000 occupation codes $\quad$ Percentage

Managerial (001-099, exclude 056, 071, 080, 086) ${ }^{1} \quad 15.09^{2}$

Professional (100-359, plus 056, 071, 080, 086, 980, 981, 982) 19.74

Med. (MD, DDS(301, 306)) 0.93

Law $(210,211) \quad 1.10$

Col \& U Teacher (220) 0.93

Other Professional Occupations $\quad 16.78$

Sales (470-499) 10.39

Office (500-599) $\quad 6.04$

Service (360-469) $\quad 9.13$

$\begin{array}{lr}\text { Farming (600-619) } & 0.89\end{array}$

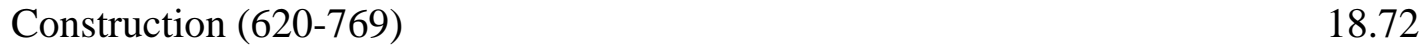

Transportation (900-979) $\quad 8.99$

\begin{tabular}{lr} 
Production (770-899, plus 983) & 11.01 \\
\hline
\end{tabular}

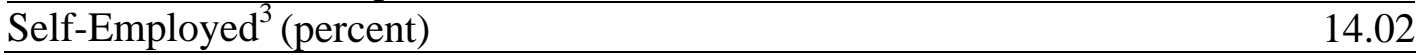

Notes:

1. Here is a partial list for the occupation codes used in this table, for a complete list, please refer to Census 2000 occupation list. 056 (compliance officers), 071 (management analysts), 080 (accountants and auditors), 086 (insurance underwriters), 980 (military officer and special tactical operations leaders/managers), 981 (military first-line enlisted military supervisors/managers), 982 (military enlisted tactical operations and air/weapons specialists and crew members), 983 (military occupation, rank not specified).

2. All the numbers are weighted using personal weight (variable 'pweight').

3. Self-employed include 'Self-employed in unincorporated business or company'; 'Selfemployed in incorporated business or company'; 'Unpaid family worker'. 
Table F-2. Census 2000 Occupation Distribution

Data source: Census 2000 PUMS one percent sample downloaded from ICPSR.

Code: Based on 2000 census occupation codes.

Sample: Adult white female age between 25 and 64 who reported occupation.

Census 2000

$\overline{\text { Occupation Category based on Census } 2000 \text { occupation codes }}$ Percentage

Managerial (001-099, exclude 056, 071, 080, 086) ${ }^{1} \quad 10.96^{2}$

Professional (100-359, plus 056, 071, 080, 086, 980, 981, 982) 28.47

Med. (MD, DDS(301, 306)) 0.36

Law $(210,211) \quad 0.52$

Col \& U Teacher (220) 0.92

Other Professional Occupations $\quad 26.67$

Sales (470-499) $\quad 11.10$

Office (500-599) 25.06

Service (360-469) $\quad 15.41$

Farming (600-619) 0.32

Construction (620-769) 0.84

Transportation (900-979) 2.03

\begin{tabular}{lr} 
Production (770-899, plus 983) & 5.80 \\
\hline
\end{tabular}

\begin{tabular}{lc}
\hline Self-Employed $^{3}$ (percent) & 8.62 \\
\hline
\end{tabular}

Notes:

1. Here is a partial list for the occupation codes used in this table, for a complete list, please refer to Census 2000 occupation list. 056 (compliance officers), 071 (management analysts), 080 (accountants and auditors), 086 (insurance underwriters), 980 (military officer and special tactical operations leaders/managers), 981 (military first-line enlisted military supervisors/managers), 982 (military enlisted tactical operations and air/weapons specialists and crew members), 983 (military occupation, rank not specified).

2. All the numbers are weighted using personal weight (variable 'pweight').

3. Self-employed include 'Self-employed in unincorporated business or company'; 'Selfemployed in incorporated business or company'; 'Unpaid family worker'. 